University of Michigan Law School

University of Michigan Law School Scholarship Repository

Articles

Faculty Scholarship

2009

\title{
Barack Obama, Margarita Lopez Torres, and the Path to Nomination
}

Ellen D. Katz

University of Michigan Law School, ekatz@umich.edu

Available at: https://repository.law.umich.edu/articles/1032

Follow this and additional works at: https://repository.law.umich.edu/articles

Part of the Election Law Commons, Law and Politics Commons, and the Supreme Court of the United States Commons

\section{Recommended Citation}

Katz, Ellen D. "Barack Obama, Margarita Lopez Torres, and the Path to Nomination." Election L. J. 8, no. 4 (2009): 369-81.

This Article is brought to you for free and open access by the Faculty Scholarship at University of Michigan Law School Scholarship Repository. It has been accepted for inclusion in Articles by an authorized administrator of University of Michigan Law School Scholarship Repository. For more information, please contact mlaw.repository@umich.edu. 


\title{
Barack Obama, Margarita Lopez Torres, and the Path to Nomination
}

\author{
Ellen D. Katz
}

\section{INTRODUCTION}

$\mathbf{I}^{\mathrm{N}}$ N THE FIRST weeks of 2008, the Supreme Court turned back a constitutional challenge to the controlling influence party leaders exerted over nominations for elective judicial office in New York State. New York State Board of Elections v. Lopez Torres found nothing unconstitutional in selecting candidates in " "smoke-filled rooms' ... dominat[ed] by party leaders." 1

The Justices said so just as national attention was turning to the critical role Democratic superdelegates were playing in the selection of the Democratic presidential nominee. These party leaders found themselves vested with controlling power to select their party's nominee independent of or even counter to the will of the party's rank and file. This power was widely seen as ill-advised and even illegitimate, ${ }^{2}$ and was why the superdelegates came to be understood as an embodiment of the smoke-filled room. ${ }^{3}$

The superdelegates, to be sure, exercised backroom decisionmaking of a nontraditional sort. They made their decisions well before the Denver convention, and did so as individuals, not as a collective body assembled in a single room, smoky or otherwise. Many superdelegates, moreover, explicitly based their decisions on the views expressed by the party's rank and file. Still, no party rule compelled the superdelegates to do so, and, in fact, the party created these "unpledged delegates" so they could rally against popular candidates they deemed unlikely to prevail in the general election. ${ }^{4}$ When this power emerged as decisive for the first time in 2008,

Ellen D. Katz is Professor of Law, University of Michigan Law School. Thanks to Jason Miller for excellent research assistance. the superdelegates came to be seen as occupants of a smoke-filled room. The image was apt, for it is this power, rather than location or atmosphere, that provides the defining characteristic of the smokefilled room.

This article compares the nomination process employed by the Democratic Party to select its presidential nominee with the one the Supreme Court upheld in the Lopez Torres decision. Specifically, it compares the nomination process Barack Obama traversed en route to the presidency with the process New Yorker Margarita Lopez Torres confronted when she sought her party's nomination to become a trial judge in Brooklyn.

These processes were, of course, vastly different in scale and public salience. Obama's presidential bid captured worldwide attention, while Lopez Torres's candidacy was barely noticed, garnering just a few isolated articles in the local press. Obama, moreover, was an unusually talented candidate, who ran a high profile, well-funded campaign that elicited passionate support and generated tremendous turnout. Lopez Torres meanwhile struggled with limited funds and voter apathy.

Hindsight, however, can be misleading. When Obama embarked on his quest for the presidency,

\footnotetext{
${ }^{1} 128$ S.Ct. 791, 799 (2008).

${ }^{2}$ See, e.g., Gail Chaddock, If Superdelegates Pick Nominee, Democrats Face Backlash, Christian Sci. Monitor, Feb. 20, 2008; Lopez. Torres and the Democrats, N.Y. Sun, Feb. 12, 2008; Ari Emanuel, My Brother the Superdelegate and Why I Don't Trust Him to Pick the Next President, The Huffington Post, Feb. 10, 2008; Theodore B. Olson, Clinton v. Obama: The Lawsuit, Wall St. Journal., Feb. 11, 2008; John Yoo, The Democrats' Super Disaster, Wall St. Journal, (March 24, 2008).

${ }^{3}$ See, e.g., Olson, supra note 2; Yoo, supra note 2.

${ }^{4}$ See Jules Witcover, Party of the People 619-20 (2003).
} 
he resembled Lopez Torres in nontrivial ways. Both were underdog candidates with credible credentials for the office they sought. Obama was a first term sitting senator who had sparked national interest but was not yet a household name; Lopez Torres was an able civil court judge who had been elected with substantial public support. Both candidates also shared the distinction of having annoyed the leaders of their party: Obama with his brash refusal to delay his bid, and Lopez Torres for refusing to make patronage hires in her civil court chambers.

What makes the comparison most appropriate, however, is that both candidates traversed complex nomination processes that were curiously similar in structure. Both systems relied on decentralized state-run primaries to select delegates to attend party-run conventions that chose the party's nominee. And in both regimes, party leaders enjoyed discretionary power to determine the nominee regardless of the views of the party's rank and file.

Operating within these regimes, Obama was able to mount a credible - and ultimately successfulchallenge to the leadership's choice for the nomination while Lopez Torres could not. This article offers an explanation why. It argues that Obama succeeded where Lopez Torres failed because the nomination process Obama traversed was more penetrable and more contestable than the one Lopez Torres faced.

In particular, the structural hurdles Obama confronted in pursuing his candidacy-from gaining access to the ballot in every state to his ability to lobby superdelegates attending the convention-were relatively and in certain respects absolutely less onerous than the ones Lopez Torres needed to navigate. Obama, moreover, faced a competitive general election once he secured his party's nomination. The nominee in the process Lopez Topez traversed did not.

Because the nomination process Obama faced was more penetrable and more contestable than the one Lopez Torres confronted, the superdelegates were forced to take Obama's candidacy seriously and they were held accountable for their decisions. Lopez Torres, by contrast, was unable to compel serious consideration of her candidacy. Party leaders ignored her with impunity.

The differences between the two nominating systems, however, do more than explain the success of one candidate and the failure of another. They also suggest that the Supreme Court may have been too hasty in dismissing the constitutional challenge to
New York State's judicial nomination system. While the Justices were quite right that a nomination process that relies on a smoke-filled room is not inherently suspect or even ill-advised, this baseline legitimacy should not have precluded further judicial inquiry. All smoke-filled rooms are not the same, and nomination processes may employ them to very different effect.

The Court in Lopez Torres feared it would be unable to distinguish the good from the bad in nominating processes that rely on backroom decisionmaking. But the differences between the process Obama traversed and the one Lopez Torres confronted are both discernible and capable of facilitating structured judicial review. Penetrability and contestability matter not because either is constitutionally required, but rather because a nominating system in which both are either wholly absent or in combination insufficiently robust may suffer from defects of constitutional dimension. Examining the degree to which a nominating process possesses these characteristics is an examination in which courts can and should engage.

The Justices may well disagree, but Lopez Torres is hardly proof that they do. Instead, the decision appears to have been animated by a distinct concern. Specifically, the Justices worried New York would replace the nominating system the lower courts invalidated with something much worse. The Court has never much liked judicial elections, ${ }^{5}$ and vindicating the complaint in Lopez Torres promised - though hardly guaranteed ${ }^{6}$ - New York would replace its "sham" judicial elections with real ones. Whatever the Justices made of the hard fought contest between Senators Obama and Clinton, they had no desire to see it replicated where judicial offices were at stake. Fine for the presidency, perhaps, but for judges, any smoke-filled room was to be preferred.

\section{TWO NOMINATING PROCEDURES}

Margarita Lopez Torres first decided to seek her party's nomination to be a state supreme court justice in New York's Second Judicial District in

\footnotetext{
5 See Republican Party of Minnesota v. White, 536 U.S. 765, 787-88 (2002); see also id. at 788-792 (O'Connor, J., concurring).

${ }^{6}$ See infra note 89 and accompanying text.
} 
1997. ${ }^{7}$ A decade later, Illinois Senator Barack Obama announced he would be seeking the Democratic Party's nomination for the presidency.

Securing the nomination to these very different offices required each candidate to traverse nomination processes that looked similar in important respects. Both candidates needed to secure the election of loyal regional delegates to attend a centralized party-run convention at which the delegates would select them to be their party's candidate. Both, moreover, needed the support of the party's leadership to prevail. Differences in detail between these processes, however, reveal why Obama succeeded and Lopez Torres failed.

\section{Ballot access}

Every state and territory issues rules governing how a candidate's name comes to appear on a primary or general election ballot. Obama needed to navigate more than fifty different sets of ballot access rules to make sure voters could choose delegates pledged to him. Lopez Torres confronted a single regime, albeit one that in many ways presented more onerous hurdles than any Obama confronted.

One way for Judge Lopez Torres to pursue the Democratic nomination for state supreme court justice was to assemble a slate of loyal delegates to run in the primary election. If elected, such delegates would attend the subsequent convention and cast their votes for her. Under New York law, such delegates run from each of the assembly districts that comprise a judicial district. In New York's Second Judicial District, 124 delegates and an equal number of alternates are elected from the district's 24 component assembly districts. ${ }^{8}$

To be placed on the primary ballot, candidates for delegate must circulate designating petitions within the assembly district in which they are running. State law gives them 37 days to gather 500 valid signatures from party members who both reside in that assembly district and who have not already signed another such petition. Because these requirements routinely render many obtained signatures invalid, those seeking access to the ballot must, as a matter of practice, obtain between one thousand and fifteen hundred signatures to ensure obtaining the required number of valid ones. ${ }^{9}$

If Judge Lopez Torres wanted to run a full slate of delegates and alternates (which the district court found a credible challenger would need to do), she needed to enlist nearly 250 people to run, and secure 124,000 qualified signatures from the various assembly districts located in Brooklyn and Staten Island that comprise the Second Judicial District. ${ }^{10}$ Accomplishing this would have required obtaining nearly a quarter million signatures, based on the lower court's "conservative" estimate of the number of signatures that must be collected to ensure obtaining a sufficient number of valid ones.

Judge Lopez Torres did not attempt to fulfill these requirements the first two times she sought her party's nomination. She hoped instead to secure the support of local party leaders. Candidates with such support need not satisfy the ballot access rules on their own, but rather may rely on party leaders to make sure that enough delegate candidates qualify for the primary ballot. The leadership (organized at the county level by the assembly district leaders) recruits candidates to serve as delegates and alternate delegates, and enlists petition circulators to obtain the requisite signatures. These petitions typically include the leadership's choices for all the offices that are at issue in the same primary election cycle. Party-endorsed slates routinely satisfy the primary ballot access requirements and typically are the only ones to do so. When unopposed, the party's slate is, under state law, "deemed elected," and the names of the delegates never appear on the primary ballot. ${ }^{11}$

Local party leaders rebuffed Judge Lopez Torres in 2003 when she sought their support, refusing to endorse her explicitly because she had refused to make patronage hires in her civil court chambers. So the third time Lopez Torres decided to try for the party's nomination, she attempted to secure delegates on her own. She amassed about 30,000 signatures, mostly from eight assembly districts, which enabled 47 delegates to run on her behalf. Fifteen of these delegates ran unopposed

\footnotetext{
${ }^{7}$ In New York, the "Supreme Court" is a trial court. The highest appellate court is called the Court of Appeals.

${ }^{8}$ N.Y. Elec. L. $\S \S 6-106,-124$; Rules of Democratic Party of the State of New York, art. II, § 5 .

${ }^{9}$ N.Y. Elec. L. §§ 6-134 (3) and (4), -136(2)(i), (3); Lopez Torres v. New York State Bd. of Elections, 411 F.Supp.2d 212, 220-221 (E.D.N.Y. 2006).

${ }^{10}$ See 411 F. Supp. 2d at 219.

11462 F.3d 161, 174-75 (2d Cir. 2006); N.Y. Elec. L. § 6-160 (2).
} 
in two assembly districts and hence were deemed elected. ${ }^{12}$

The remaining 32 delegates Lopez Torres enlisted ran in contested races. Their names appeared on the primary ballot, but Lopez Torres' name did not. New York law prohibited listing the delegates' affiliation with Judge Lopez Torres. Two of these 32 delegate candidates were elected, giving Judge Lopez Torres 17 delegates slated to attend the 2003 convention. ${ }^{13}$

Consider, by contrast, the rules Barack Obama confronted when he decided to seek the Democratic Party's nomination. Obama needed to get his name on the ballot in each state primary or caucus contest. The process he navigated was a complex one, governed by a mix of rules promulgated by the Democratic National Committee (DNC), the respective state Democratic parties, and the legislatures of the states where primaries or caucuses occurred.

The DNC established the overall structure for the 2008 nomination process. It selected a convention date and location. It decided that primary voters and caucus participants nationwide would select more than 3,000 pledged delegates to attend this convention, apportioned by a formula meant to account both for population and the degree of past support for the party in the state. These delegates would be awarded proportionally to any candidate receiving at least 15 percent of the vote in each congressional district. The DNC also created the well-known and much discussed superdelegates, consisting of party officials, Democratic Congress members and governors, and other prominent Democrats, who would vote as they chose at the convention. ${ }^{14}$

Back in August 2006, the DNC called on each state party to develop and adopt plans that would govern delegate selection in its state. State party plans were subject to DNC approval, and needed to comply with several structural constraints the DNC imposed. Among these constraints, DNC rules required that state parties publicize the time and location of all official meetings related to delegate selection (including caucuses and conventions); that they comply with a set calendar and complete their selection processes no later than June 10, 2008; that they ensure that the listing of all delegate candidates on convention, caucus, and primary ballots specify the presidential candidate they support; and that they require no more than 5,000 signatures or a fee not exceeding $\$ 2,500$ as a precondition to placing the name of a presidential candidate on the ballot. ${ }^{15}$ DNC rules also limited participation in the delegate selection process to voters who "publicly declare or enroll as Democrats." 16

State parties in turn developed their plans. Thirtysix state Democratic parties along with those in the District of Columbia, Puerto Rico, and the Virgin Islands opted to participate in state-run primaries as their method to select delegates. ${ }^{17}$ Several of these participated in state regimes that were not in full compliance with DNC requirements. Some state parties sought waivers from the DNC for noncomplying state procedures or pledged to seek legislative change to bring the State into compliance. ${ }^{18}$ Others simply participated in noncompliant primaries.

Most famously, the state parties in Florida and Michigan agreed to participate in state-run primaries scheduled ahead of the dates permitted by DNC rules, a decision that led the DNC's rules committee first to exclude entirely the delegates selected and subsequently to allow such delegates to participate while halving their vote. ${ }^{19}$ The DNC chose, however, not to penalize other state parties that participated in noncompliant state regimes. Iowa, New Hampshire, and South Carolina, for instance, all held their contests on dates that did not comply with

12411 F. Supp.2d at 235, n. 34; 462 F.3d at 178-79.

${ }^{13}$ Id. at n. 34

${ }^{14}$ See Call of the Democratic Convention, Article I, B, I, J, $<$ http://www.democrats.org/page/-/pdf/FINAL2008CalltotheConvention.pdf>; DNC Delegate Selection Rule 9, 13B. The precise number of superdelegates was not known until the convention itself, due to demographic changes in the number of officials eligible for the designation. See Adam Nossiter, Democrat Wins House Seat in Mississippi, N.Y. Times, May 14, 2008. ${ }^{15}$ DNC Delegate Selections Rules 1, 3, 4, 6, 11, 12, 14.A and B.

${ }^{16}$ DNC Delegate Selection Rules 2.A.1.

17 See Delegate Selection Plans (DSP) for the State Democratic Party in Alabama, Arizona, Arkansas, California, Connecticut, Delaware, District of Columbia, Florida, Georgia, Illinois, Indiana, Kentucky, Louisiana, Maryland, Massachusetts, Michigan, Mississippi, Missouri, Montana, New Hampshire, New Jersey, New York, North Carolina, Ohio, Oklahoma, Oregon, Pennsylvania, Puerto Rico, Rhode Island, South Carolina, South Dakota, Tennessee, Texas, Utah, Vermont, Virgin Islands, Virginia, West Virginia, Wisconsin. The Texas Democratic Party opted into the state regime for the selection of 126 of the state's pledged delegates, with the remaining 67 selected in three-tiers of party-run caucuses. See DSP for Texas.

18 See DSP for New York, Tennessee, West Virginia.

${ }^{19}$ See Katharine Q. Seelye and Jeff Zeleny, Democrats Approve Deal on Michigan and Florida, N.Y, TIMES, June 1, 2008. 
the ones authorized by the $\mathrm{DNC},{ }^{20}$ while Virginia required presidential candidates to obtain 10,000 signatures to qualify for the ballot, notwithstanding the DNC's 5,000 signature cap. ${ }^{21}$

Parties opting to participate in state-run systems confronted varied levels of state regulation. Some states played a limited role, paying for the costs to run the primary and imposing a few general constraints, but otherwise letting the state party define the rules for participation, including how candidates would qualify for the ballot. ${ }^{22}$ Other states regulated the delegate selection process more closely, granting ballot access to candidates based on factors such as a national reputation, eligibility for federal matching funds, payment of a fee, obtaining a requisite number of signatures, or some combination of these requirements. Where authorized by a state to set ballot access rules, parties participating in state-run primaries imposed relatively modest signature and fee requirements. ${ }^{23}$

Fifteen state parties chose not to participate in state-run systems at all, or in the case of Texas, not exclusively, and held party-run caucuses typically on dates that preceded the state-run primaries. ${ }^{24} \mathrm{Bal}-$ lot access in caucus states generally required nothing more than a request by the candidate for inclusion, ${ }^{25}$ or payment of a modest fee. ${ }^{26}$

Operating within this framework, Obama secured access to the ballot in all fifty states and the participating territories. ${ }^{27}$ The applicable rules qualified Obama automatically in 29 states based on his status as a "national candidate" and his eligibility for federal matching funds. Obama needed to pay $\$ 28,825$ to gain access to the ballot in an additional seventeen contests. Finally, Obama needed to collect twenty-nine thousand qualifying signatures to get his name on the ballot in the remaining ten states. At the close of the process, Obama had secured 1,766.5 pledged delegates, compared with Hillary Clinton's $1,639.5 .^{28}$

All told, Obama confronted ballot access rules that enabled him to compete meaningfully for the Democratic presidential nomination. Judge Lopez Torres faced rules that effectively doomed her effort to compete for her party's nomination. DNC rules ensured that Obama's name appeared on primary ballots next to the delegate candidates pledged to him; ${ }^{29}$ New York law kept Judge Lopez Torres's name off the ballot entirely, and barred delegate candidates from identifying their allegiances on the ballot. ${ }^{30}$ DNC rules mandated proportional allocation of delegates, allowing Obama to capture a significant number of delegates even in states where he lost the popular vote; New York law gave Lopez Torres no similar opportunity.

DNC rules, moreover, capped the number of signatures Obama needed to get on the ballot and in many places rules adopted by states and state parties reduced or eliminated that number entirely. Even if Obama collected twice the minimum number required (to ensure a sufficient number would qualify), he still needed to collect no more than 60,000 signatures nationwide. Lopez Torres, by contrast, did not come close to collecting the nearly

20 See DNC Rule 11.A (specifying that the Iowa, Nevada, New Hampshire, and South Carolina contests "may be held no earlier than" 22 days, 17 days, 14 days, and 7 days, respectively, prior to the first Tuesday in February). See also Election Guide 2008: Primary Calendar: Democratic Nominating Contests, N.Y. TIMES, <http://politics.nytimes.com/election-guide/2008/ primaries/democraticprimaries/index.html $>$ (last access $\mathrm{Au}-$ gust 2, 2008) (reporting dates of actual contests that deviate from dates set by DNC Rule 11.A: Iowa's on January 3 rather than January 14, New Hampshire's on January 8 not January 22 and not before Nevada's, and South Carolina's on January 19 not January 29).

${ }^{21}$ Virginia Code $\$ 24.2-545$ (10,000 qualified voters, including at least 400 qualified voters from each congressional district in the Commonwealth, who attest that they intend to participate in the Democratic primary).

22 See, e.g., South Carolina Code § 7-11-20.

${ }^{23}$ See, e.g., DSP for South Carolina, Title VI, (\$2,500 filing fee or 3,000 signatures); Arizona (\$2,500); District of Columbia $(\$ 2,500)$; Louisiana ( $\$ 375$ fee to party after $\$ 750$ qualifying fee to state).

${ }^{24}$ See DSP for Alaska, Colorado, Hawaii, Idaho, Iowa, Kansas, Maine, Minnesota, Nebraska, Nevada, New Mexico, North Dakota, Washington, Wyoming. The Texas state party opted both to participate in the state-run primary and hold party-run caucuses. See Texas DSP. Democratic Parties in American Samoa and Guam also opted to hold caucuses.

${ }^{25}$ See DSP for Colorado, Idaho, Iowa, Maine, Nebraska, Nevada, North Dakota, Washington.

26 See DSP for Alaska $(\$ 1,000)$; Hawaii $(\$ 2,500)$; Kansas: $(\$ 1,000)$; New Mexico $(\$ 2,500)$.

27 Obama subsequently removed his name from the Michigan ballot following the DNC's decision to strip the state of its delegates for noncompliance with the primary calendar. Four Democrats withdraw from Michigan primary (AP Wire), US News, 10/9/2007, <http://www.usatoday.com/news/politics/ election2008/2007-10-09-mich-primary_N.htm>.

${ }^{28} \mathrm{See}<\mathrm{http} / / / \mathrm{www}$. realclearpolitics.com/epolls/2008/president/ democratic_delegate_count.html $>$.

${ }^{29}$ DNC Delegate Selection Rule 12.

${ }^{30}$ Lopez Torres v. New York State Bd. of Elections, 411 F.Supp.2d 212, 220 (E.D.N.Y. 2006). 
250,000 signatures she needed to run a full slate of loyal delegates and alternates in a single judicial district within New York State.

\section{Lobbying convention delegates}

Neither Lopez Torres nor Obama won enough pledged delegates to secure their party's nomination. Both accordingly sought to lobby convention delegates to support their candidacies. Once again, Obama was successful, Lopez Torres was not.

New York law does not compel delegates elected on the leadership's slate to vote for the leadership's candidates. Lopez Torres accordingly sought to persuade these delegates to vote for her at the convention, but, as the district court found, "[t]he structural and practical impediments" she confronted in this attempt were "insurmountable." 31

Lopez Torres could not easily identify the delegates. During her 2003 attempt at the nomination, she repeatedly asked the Kings County Democratic Committee to identify the delegates, but was rebuffed. Even if Lopez Torres knew whom she needed to contact, New York law gave her what the appellate court deemed "an unrealistically brief" period of time in which to contact them. State law mandates that the party convention be held two weeks after the judicial delegates are elected, a period during which Lopez Torres would have needed to contact and persuade a majority of the 248 delegates and alternates of the merits of her case. ${ }^{32}$

Finally, even if Lopez Torres had sufficient time to lobby the delegates, she would have failed to persuade them of anything. The lower courts found that the delegates slated by the party are not susceptible to persuasion, that they "do not exercise their own judgment when deciding which candidate to support," and they "do not actually perform [a] deliberative, consultative, informed role[]." Instead, "without consultation or deliberation, [they] rubber stamp the county leaders' choices (or 'package' of choices) for Supreme Court Justice." ${ }^{33}$ The district court explained why: "[The delegates] do not and will not jeopardize their ongoing, multifaceted relationships with other district leaders and the county leaders over a candidate for Supreme Court Justice."34

Barack Obama faced no comparable obstacles when he sought to lobby delegates to the Demo- cratic National Convention. DNC rules set the convention date, and state parties identify their pledged delegates months before the convention. ${ }^{35}$ DNC rules, more importantly, identified virtually all the superdelegates much earlier. These rules meant Obama could easily identify the delegates and that he had sufficient time to make his case to them.

Obama also confronted decisionmakers susceptible to persuasion. Superdelegate support for Hillary Clinton might have "seemed like a safe bet" before the primary season began, but by March, "superdelegates were showing an independence that the Clinton campaign had not counted on." 36 Both Obama and Clinton aggressively lobbied the superdelegates, with the media carefully tracking the ever changing allegiances of this critical group. Obama's campaign was able to convince many superdelegates to side with him.

Superdelegates announced their support in public fora and offered varied reasons for it. Of those endorsing Obama, some said they based their support on specific traits they thought he possessed, while others announced they were following the election returns, either from their district or more generally. ${ }^{37}$ These announcements added to Obama's tally and influenced other superdelegates to sign on as well. ${ }^{38}$

31411 F. Supp.2d at 217.

32411 F. Supp.2d at 224, 225; 462 F.3d. at 176; N.Y. Elec. L. $\S 6-158$.

33411 F. Supp. 2d at 223, 224; 462 F.3d at 176.

34411 F. Supp.2d at 223; see also 462 F.3d at 177 ("the party leadership possesses the power to doom a delegate's political career if she should reject its choice for Supreme Court Justice").

${ }^{35}$ See < $<$ ttp://www.indems.org/content/2008_democratic_national_convention_delegate_apportio nment $>$.

${ }^{36}$ See Katharine Q. Seelye, For Clinton, a Key Group Didn't Hold, N.Y. Times, June 5, 2008.

${ }^{37}$ See, e.g., Gregory Roberts, Obama Picks Up Another Washington Superdelegate, Seattle Post-Intelligencer, May 9, 2008; Julie Bosman, The Superdelegate Tally, June 3, 2008, $<$ http://thecaucus.blogs.nytimes.com/2008/06/03/the-superdelegate-tally/index.html?hp $>$; Jeff Zeleny and Patrick Healy, Black Leader, a Clinton Ally, Tilts to Obama, N.Y. Times, Feb. 15, 2008; Loyalty vs. Voters: A Superdelegate's Dilemma, <http://www.npr.org/templates/story/story.php?story Id $=19096400>$.

${ }^{38}$ See, e.g., Andrew Sullivan, John Lewis Switches, Theatlantic.com, Feb. 15, 2008, <http://andrewsullivan.theatlantic.com/the_daily_dish/2008/02/john-lewis-swit.html>. 
Both Obama and Clinton made campaign contributions to various superdelegates. ${ }^{39}$ These contributions were a matter of public record, but unsurprisingly were not among the reasons cited by superdelegates for their support.

By mid-May, more superdelegates had pledged their support for Obama than for Clinton. ${ }^{40}$ By the day of the last primary, enough superdelegates sided with Obama to give him the votes he needed to secure the nomination.

\section{The convention}

Every four years, delegates to the Democratic National Convention select the party's nominee for the presidency. In recent years, this convention has been a four-day affair, televised nationally, attended by thousands. More than 19,000 people attended the 2008 Denver convention, and Obama accepted the nomination at Invesco Field in front of more than 80,000 people.

A Democratic convention of a very different sort selects the party's nominees for trial judge in New York's Second Judicial District. This convention is held without public disclosure of its time or place, attendance is limited to the delegates themselves, and the whole affair is over in a manner of minutes. ${ }^{41}$ The 2002 convention for the Second Judicial District took place in the main jury room of a Brooklyn courthouse during the lunch hour. As one delegate later observed, "You go in, it's 12 o'clock, and you are out at 12:30." 42

These conventions differ in almost every respect, save one. Both conventions dispensed entirely with deliberation and instead nominated a candidate selected elsewhere. New York's judicial conventions are "perfunctory, superficial events ... [that] rubber stamp the major party leaders' choices for Supreme Court Justice." ${ }^{43}$ Democratic National Conventions were once the locus for real decisionmaking but today are scripted affairs that approve but do not select a nominee. ${ }^{44}$

That the 2008 convention would follow the modern approach was momentarily uncertain. Senator Clinton, whose supporters constituted a majority of the DNC's Rules and Bylaws Committee, consistently argued that the delegates selected in the Michigan and Florida primaries should be seated at the convention, notwithstanding the Committee's earlier decision to exclude these delegations for noncompliance with the DNC's primary schedule. ${ }^{45} \mathrm{In}$
May, the Committee voted to seat the delegates but to halve their voting power, a resolution that did not give Clinton the boost she needed to fight on after the Montana and South Dakota primaries on June 3. Had the Committee ruled otherwise, Clinton might have continued her campaign, perhaps to the convention floor itself.

No comparable contest would have been possible in New York. State law requires the party to seat all delegates elected through the primary process, ${ }^{46}$ thereby eliminating the prospect of competing or discredited slates of delegates. This rule-assuming it is enforceable ${ }^{47}$-facially protects any delegates a challenger candidate manages to secure by guaranteeing them a seat at the convention. Still, the ballot access rules ensure few such delegates will emerge from the primary, while the seating mandate itself eliminates one means for challenger candidates to dispute reported irregularities in the delegate selection process. Thus, even if Lopez Torres knew, as was later reported, that some of the delegates to the 2002 convention were "technically in-

${ }^{39}$ See, e.g., Foon Rhee, Key Superdelegate Switches to Obama: Candidates Contribute to Superdelegates, The Boston Globe, Feb. 15, 2008.

40 See Jake Tapper, Obama Takes Lead in Superdelegate Tally, $<$ http://abcnews.go.com/Politics/Vote2008/Story?id=481863 $7 \&$ page $=1>$.

${ }^{41}$ New York State requires that a party hold its judicial nominating convention two weeks after the primary election, see N.Y. Elec. law§ 6-158 (5), and that it comply with several procedural requirements. § 6-126. State law does not require the party to make public the specific time and place of the convention. According to evidence in the district court, one convention lasted eleven minutes, another twenty. 411 F. Supp. 2d at $228,230$.

42 Clifford J. Levy, Picking Judges: Party Machines, Rubber Stamps, N.Y. Times, July 20, 2003.

43411 F. Supp. 2d at 229. See also Erik Engquist, Judicial Reform Sought (Sept 6, 2004), <http://www.lidbrooklyn.org/ bp090604.htm>.

${ }^{44}$ See, e.g., Byron E. Shafer, Quiet Revolution: The Struggle for the Democratic Party and the Shaping of PostReform Politics (1983).

45 Thomas Edsall, Clinton Camp Says It Will Use The Nuclear Option, (May 4, 2008), < http://www.huffingtonpost.com/2008/ 05/04/clinton-camp-considering_n_100051.html > .

${ }^{46}$ N.Y. Elec. L. § 6-124.

47 The absence of serious challenge to the leadership's slate means party officials have had no cause to dispute primary results. Were they, however, to be so inclined, the state's mandatory seating requirement might be subject to challenge as an infringement on party autonomy. See generally Democratic Party of U.S. v. Wisconsin ex rel. La Follette, 450 U.S. 107 (1981); Cousins v. Wigoda, 419 U.S. 477 (1975); Nelson v. Dean, 528 F.Supp. 2d 1271 (N.D. Fla. 2007). 
eligible" to participate, state law facially precluded her from challenging their participation at the convention. ${ }^{48}$

\section{The post-convention period}

The convention would seemingly mark the end of a comparative account of how Obama secured his party's nomination and Lopez Torres failed to do so. And yet, the post-convention periods that followed the respective conventions differed significantly and did so in a manner that shaped the nominating processes that preceded them. Needless to say, securing the Democratic Party's nomination hardly guaranteed Obama the presidency. The specter of the general election loomed over the primary season, with both Senators Obama and Clinton constantly arguing their relative merits not just against one another, but against the presumptive Republican nominee John McCain.

Not so for the race for trial judge in New York's Second Judicial District. Had Judge Lopez Torres secured her party's nomination, she would have become a state supreme court justice. The lower courts in Lopez Torres noted that the general election for that office plays "almost as minor a role" as does the convention, and "one-party rule is the norm in most judicial districts." 49

Lopez Torres unsuccessfully attempted to challenge one-party rule in 2003. Having failed yet again to get her party's nomination, she ran in the general election with a slate of candidates sponsored by the Working Families Party. Headlines during the preceding months highlighted corruption among sitting Brooklyn Democratic judges and the party leaders involved with their selection. The New York Times endorsed Lopez Torres and the slate with which she ran, calling on voters "to register their disgust with the hack-infested local bench and the clubhouse-driven selection process, and ... [to] elect some good, politically independent judges." Lopez Torres and her fellow candidates lost to the Democrats by a margin of three to one. ${ }^{50}$

\section{TWO FACETS OF A NOMINATION PROCESS}

Obama and Lopez Torres confronted structurally similar nomination processes that nevertheless differed in important respects. The process Obama nav- igated was more penetrable and more contestable than was the one Lopez Torres traversed. This section explores these differences and seeks to explain why they matter.

\section{Penetrability}

Unlike a traditional smoke-filled room, which by definition is wholly impenetrable to outsiders, the nomination processes Obama and Lopez Torres faced expressly invited participation by party members. Both candidates accepted the invitation. Obama encountered a system that allowed for meaningful participation; the one Lopez Torres confronted proved to be impenetrable in practice.

Securing the Democratic Party's nomination for the presidency required Obama to navigate scores of complex electoral rules. This process, while densely regulated, was nevertheless penetrable. The ballot access rules enabled Obama to get his name on primary ballots; the rules governing the allocation of delegates prevented Obama's defeat in places like California from becoming ruinous; and the rules mandating a lengthy and serialized process ensured that Obama could effectively lobby delegates and exploit sequential victories and near-victories.

The rules Obama confronted might well have been different. More stringent ballot access rules might have kept Obama's name off the ballot while allocating delegates based on a winner-take-all approach might have ended the Obama candidacy on Super Tuesday. ${ }^{51}$ A decision by the DNC early on to count the Michigan and Florida returns in full (or never to have excluded them in the first instance) might well have secured Hillary Clinton's success.

But the rules were what they were, and they allowed Obama to succeed in critical early battles, remain viable through Super Tuesday, and claim frontrunner status by late February. Once Obama got that far, he could not be ignored. Those who ultimately decided the nomination were forced to con-

\footnotetext{
48 See Levy, supra note 42.

49411 F. Supp.2d at 217; 462 F.3d at 178.

${ }^{50}$ What's This? An Actual Judicial Election, N.Y.Times, Nov. 1, 2003; see also The Sun Palm Card, The New York Sun, Nov. 4, 2003; Andy Newman, The 2003 Election: Judges, Democrats Keep Hold on Judgeships in Brooklyn, N.Y.TIMEs, Nov 5, 2003.

51 See, e.g., A Primer on the All-Important Role of Delegates, $<$ http://www.motherjones.com/mojoblog/archives/2008/02/70 80_a_primer_on_the.html>.
} 
front his candidacy, consider him seriously, and explain their decisions.

Lopez Torres enjoyed no comparable access and hence received no comparable consideration. As the district court found, challenger candidates like Lopez Torres could not "clear all the hurdles necessary to elect supportive delegates." They confronted "insurmountable" obstacles in seeking to lobby the delegates elected on the party's slate. ${ }^{52}$ Both in design and effect, the New York's system was functionally impenetrable. ${ }^{53}$

The impenetrability of the New York system helps explain why the delegates to the judicial nominating convention in Brooklyn were not identified publicly and Lopez Torres could not readily determine their identities. It was why the delegates themselves felt no compulsion to offer any explanation for their votes and why they proceeded to vote with virtually no information whatsoever about the people they nominated. ${ }^{54}$ This absence of penetrability meant the party leaders who actually selected the nominees the convention ratified had no reason to offer a public explanation for their decisions-decisions the district court found to be based on the nominee's willingness to comply with the party's patronage system and to contribute financially to party leaders. ${ }^{55}$ In short, party leaders gave no serious consideration to the candidacy of Judge Lopez Torres because they had no cause to do so.

\section{Contestability}

Following his nomination, Obama faced a general election everyone assumed would be competitive. This assumption shaped Obama's path to the nomination. All the Democratic candidates in 2008 presented themselves as the best choice to beat the Republicans in November and the superdelegates prominently cited this interest in victory when pledging their support. ${ }^{56}$

No comparable concern arose in New York's Second Judicial District, where securing the Democratic nomination is tantamount to election as state supreme court justice. To be sure, no legal obstacle prevents those aspiring to this office from running in the general election as an independent or third party candidate. New York's requirements for doing so are, in fact, relatively undemanding. ${ }^{57}$ But reality is something different entirely. Both gerrymandering and pure demographics have ensured that New York's judicial districts are wholly noncom- petitive, such that the general election is not a locus of real decisionmaking. The New York Times accordingly noted with some surprise Lopez Torres's 2003 effort to challenge party dominance, headlining its endorsement of her third party candidacy with the query: "What's This? An Actual Judicial Election." 58 Turns out, it wasn't, and Lopez Torres was routed.

The fact that nomination is tantamount to election critically shapes the incentives of the party leaders who control the nomination process. Where competitive, the general election functions as a protective device and imposes a structural constraint on leadership discretion to select the party nominee. ${ }^{59}$ It counsels party leaders to consider seriously challenger candidates, or to ignore them at their peril. Contestability serves as quality control, creating a disincentive to select candidates ill-suited for the office they seek. ${ }^{60}$

Contestability may exist prior to or indeed in lieu of a contested general election. A contested nomination process (be it a primary or convention) may similarly function to vet candidate qualifications and ensure accountable decisions. Even a noncompetitive nomination process controlled solely by party leaders may be subject to indirect contest insofar as party members unhappy with the nominees selected are able to voice their opposition or challenge the leaders who selected them.

The system Lopez Torres faced was functionally uncontestable at each of these junctures. The general election was a rubber stamp, while burdensome

52411 F. Supp. 2d at 217.

53 See, e.g., 462 F.3d 161, 175, 177 (2d Cir. 2006).

54 See 411 F. Supp. 2d 212, 236 (E.D.N.Y. 2006); Levy, supra note 42.

55411 F. Supp. $2 d$ at 233.

56 See supra note 37 and accompanying text.

57 See 128 S.Ct. at 802 (Kennedy, J., concurring).

58 See N.Y. Times, Nov. 1, 2003.

${ }^{59}$ See also Christopher S. Elmendorf, New York State Bd. of Elections v. Torres: Is the Right to Vote a Constitutional Constraint on Partisan Nominating Conventions?, 6 ELECTION L. J. 399, 400, 408 (2007); James A. Gardner, New York's Judicial Selection Process is Fine-It's the Party System That Needs Fixing, 79 N.Y. ST. B.J. 42, 45 (Sep. 2007); Daniel Lowenstein, Associational Rights of Major Political Parties: A Skeptical Inquiry, 71 Tex. L. REV. 1741, 1768 (1993).

${ }^{60}$ A disincentive notably absent in New York. See Commission to Promote Public Confidence in Judicial Elections, Final Report to the Chief Judge of the State of New York, $<$ http://www.nycourts.gov/reports/FerrickJudicialElection.pdf $>$, Feb. 6, 2006. 
ballot access law left most primaries uncontested. The very existence of the state-run primary system, moreover, distracted attention from the control party leaders exerted and rendered more difficult an internal contest of the leadership role in the process.

The lack of contestability helps explain the persistence of New York's judicial nominating process. Good government groups have long complained about the system, editorial boards have demanded reform, and criminal indictments have periodically highlighted the corruption the system facilitates. ${ }^{61}$ The Lopez Torres litigation itself, with its multiple opinions from three courts, offered a scathing critique of the State's system. Justice Stevens went so far as to suggest that New York's system was "stupid." 62 While many (including all nine justices) have defended the regime's legality, and some praised its purported ancillary benefits, ${ }^{63}$ absent throughout has been vigorous internal debate about the merits of the system. ${ }^{64}$

Contrast this system with the DNC's nomination process and the vigorous debate it generated among party leaders, party members, and observers generally. Some praised the superdelegates' independence; ${ }^{65}$ others celebrated their role in ending the process by June, thereby providing a clear winner in a close race. ${ }^{66}$ Those unhappy with the power DNC rules gave to the superdelegates complained, blogged, and voted; ${ }^{67}$ some threatened defection, some may have defected, and some promised retaliation against those superdelegates holding elective office. ${ }^{68}$ In this highly contested regime, voice was readily implemented, exit even more easily exercised.

\section{JUDICIAL REVIEW AND THE SMOKE-FILLED ROOM}

The Supreme Court in Lopez Torres never questioned the district court's finding that New York's system was functionally both impenetrable and uncontestable. In fact, the decision reads as if the Court would have upheld the New York regime no matter how impenetrable or uncontestable it was. Narrower holdings were available, ${ }^{69}$ but a more circumscribed approach would have invited future challenges to other smoke-filled rooms. The Court bluntly stated that it was unwilling to extend that invitation. ${ }^{70}$ Perhaps envisioning lawsuits brought by disgruntled Democratic voters unhappy with the su- perdelegates, Justice Scalia insisted that the Court was ill-suited to distinguish among smoke-filled rooms. $^{71}$

On this point, Justice Scalia sounded a lot like Justice Frankfurter, who famously pressed a similar argument in Baker v. Carr and lost. ${ }^{72}$ The Court, of course, has never quite overcome that nagging suspicion that Frankfurter may have been right and that Baker launched a foray into the political thicket that might wisely have been avoided. ${ }^{73}$ The Court's deferential posture in Lopez Torres reflects this suspicion.

This unwillingness, while welcomed by some, ${ }^{74}$ is cause for concern. Bright lines distinguishing one

61 See, e.g., It's Time To Change A Stupid Law, Newsday.com, Jan. 18, 2008; Supreme Task for Silver, N.Y. DaILy News, Jan. 18, 2008; Anemona Hartocollis, Clarence Norman is Guilty of Illegal Campaign Contributions, N.Y. Times, Sept. 27, 2005. 62128 S.Ct. at 801 (Stevens, J, concurring).

${ }^{63}$ See, e.g., 411 F. Supp. 2d 212, 250 (E.D.N.Y. 2006).

${ }^{64}$ For example, the New York Times called the odds for reform "long, since the powers that be in the Legislature are the same ones that profit from the current corrupt system." A Defeat for Judicial Reform, N.Y.TIMES, Jan. 17, 2008.

65 See, e.g., Lanny Davis, The "Superdelegates": Always Intended to be Independent, Feb. 13, 2008, < http://www.huffingtonpost. com/lanny-davis/the-superdelegates-alw_b_86567.html $>$; Geraldine A. Ferraro, Got a Problem? Ask the Super, N.Y. TIMEs, Feb. 25, 2008.

66 See, e.g., John K. Wilson, In Praise of Superdelegates: Why the Democratic Party Delegate Process Worked, June 3, 2008 $<$ http://www.dailykos.com/story/2008/6/3/165646/4106?new $=$ true $>$; Ron Klain, In Praise of the Primary Slog, NYTimes.com, June 9, 2008.

${ }^{67}$ See, e.g., Adam Nagourney, A Primary Calendar Democrats Will Never Forget, N.Y. TIMEs, June 2, 2008; Harkin Wants Democrats to Ditch Superdelegates, Des MoINes Register, Feb. 15, 2008; Primary Reforms, N.Y. Times, June 8, 2008.

${ }^{68}$ See, e.g., Lopez Torres and the Democrats, N.Y. SUN, Feb. 12, 2008 (noting DNC member Donna Brazile's statement on CNN that "If 795 of my colleagues decide this election, I will quit the Democratic Party"); Shaila Dewan, Obama Plays a Part in Contests in Georgia, N.Y. TIMES, July 16, 2008 (noting Rep. John Lewis, who initially endorsed Clinton, faced primary challenges for the first time since 1992).

69 See Elmendorf, supra note 59, at 400.

70128 S.Ct. at 800.

71128 S.Ct. at 800

72 See Stephen Ansolabehere and Samuel Issacharoff, The Story of Baker v. Carr, in Constitutional Law Stories (Michael C. Dorf, ed., 2004), at 316.

${ }^{73}$ See, e.g., Vieth v. Jubilirer, 541 U.S. 267 (2000); California Democratic Party v. Jones, 530 U.S. 567 (2000) (Stevens, J. dissenting); Holder v. Hall, 512 U.S. 874 (1994) (Thomas, J., concurring).

${ }^{74}$ See, e.g., Marci Hamilton, The Supreme Court's Recent Opinion in New York State Board of Elections v. Lopez Torres: A Wise Decision to Stop Meddling in the States' Primary Systems, FindLaw, Jan. 24, 2008, < http://writ.news.findlaw.com/ hamilton/20080124.html>. 
complex nomination process from another may prove elusive, but that difficulty alone does not mean meaningful distinctions are either impossible or unnecessary. Nor does it suggest that this arena presents questions that are categorically different from other knotty subjects with which the Court has long engaged. ${ }^{75}$ Some distinctions will prove more lasting than others, but drawing them case by case is a staple of what the Court has long done and what it should continue to do.

In Lopez Torres, moreover, the Court did not so much refuse to enter a new arena as retreat from one it had long regulated. Unlike Baker or other, more recent manifestations of the question, ${ }^{76}$ Lopez Torres did not require the Court to break wholly new ground. The Justices have long engaged in constitutional review of state-mandated nomination processes and long recognized that such processes implicate protected participatory and associational interests. ${ }^{77}$ To be sure, not every foray into this realm has been adequately theorized ${ }^{78}$ and some might well be reconsidered. ${ }^{79}$ But the legal landscape governing nomination processes has long reflected the Court's involvement and withdrawal now leaves standing an incomplete and skewed regulatory regime.

New York, of course, might have dispensed with primaries entirely, and it might have left the conventions that followed unregulated. Instead, the State chose to adopt a hybrid nomination process that both grants the right to vote in primary elections and mandates - and in important respects directs-the conventions that follow. Once it chose to do this, constitutional obligations attached. ${ }^{80}$ Or at least they should have. The Court in Lopez Torres expressed surprising skepticism on this point. At oral argument, for example, Chief Justice Roberts said he thought "it seem[ed] kind of odd, that if a State can have no role for voters, it can have a pure convention, that they're penalized if they have some role for voters?" 81 That a greater power does not necessarily encompass the lesser should hardly have been surprising. ${ }^{82}$

The Court's retreat in Lopez Torres is, moreover, incomplete. Leaving disputes of this sort to the political process has undeniable allure, but Lopez Torres fails to secure this result. The decision invites party leaders to enlist and rely on state law as the primary vehicle for party governance, largely relieving these leaders of any need to secure the support or acquiescence of party members to a chosen course. Why bother to persuade party members to adopt or accept a rule when the legislature will mandate it as a matter of law? Furthermore, placing what appears to be constitutional significance on the litigating positions of the state parties, ${ }^{83}$ the Court privileged the party machines in a manner that guarantees litigation. Should party leaders fail to get what they want from the legislature, they will sue, claiming the undesired outcome amounts to a denial of associational freedom. ${ }^{84}$

Lopez Torres accordingly does what a prominent proponent of judicial restraint in this realm has counseled against: it gives party organizations a constitutional position "that immunizes them from the results of the give-and-take" of the political process, and thereby favors "unaccountable and generally obscure party officials." 85 Associational interests may be understood in such terms, to be sure, but whether they remain worth protecting once they are is another matter.

${ }^{75}$ Cf. Holder v. Hall, 512 U.S. 874, 965 (1994) (Steven, J., dissenting) ("Our work would certainly be much easier if every case could be resolved by consulting a dictionary").

${ }^{76}$ See, e.g., Vieth, 551 U.S. at 277-90.

77 See, e.g., Kusper v. Pontikes, 414 U.S. 51 (1973); United States v. Classic, 313 U.S. 299 (1941).

78 See Samuel Issacharoff, Private Parties With Public Purposes: Political Parties, Associational Freedoms, and Partisan Competition, 101 Colum. L. Rev. 274 (2001).

${ }^{79}$ See, e.g., Lowenstein, supra note 59; Bruce Cain and Nathanial Persily, The Legal Status of Political Parties: A Reassessment of Competing Paradigms, 100 Colum. L. Rev 775 (2000).

80 See, e.g., Harper v. Virginia, 383 U.S. 663 (1966) ("once the franchise is granted to the electorate, lines may not be drawn which are inconsistent with the Equal Protection Clause of the Fourteenth Amendment.").

${ }^{81}$ New York State Board of Elections v. Lopez Torres, Oral Argument Transcript, at 30.

82 See, e.g. Federal Election Com'n v. Wisconsin Right to Life, Inc., 127 S.Ct. 2652 ("This great-includes-the-lesser approach is not how strict scrutiny works"); Meyer v. Grant, 486 U.S. 414, 424-425 (1988) (rejecting argument that greater power to end voter initiatives includes lesser power to prohibit paid petition-circulators); Kramer v. Union Free School District No. 15, 395 U.S. 621 (1969) (school board positions need not be elective, but once they are, strict scrutiny applies to restriction on the franchise); Avery v. Midland County, 390 U.S. 474 (1968) (one person, one vote rule applies to local elective officers, even though offices might have been filled by appointment).

${ }^{83}$ See Elmendorf, supra note 59, at 407; Richard Winger, Lopez Torres Decision is of Abysmal Quality, Ballot Access News (Feb 1, 2008) available at <http://www.ballot-access.org/ 2008/020108.html\#1>.

${ }^{84}$ See Elmendorf, supra note 59, at 407-08.

${ }^{85}$ Lowenstein, supra note 59, at 1771. 
A more sound approach would embrace substantive review of state-mandated nomination processes ${ }^{86}$ while expressly recognizing that regimes that vest power in party leaders differ in important ways. Lines are needed, and some will be difficult to draw, but manageable and discernible distinctions may indeed be made.

Comparing Obama's success with Lopez Torres's failure shows how. The nominating process Obama traversed was more penetrable and more contestable than was the one Lopez Torres confronted. Penetrability and contestability matter here not because they are constitutionally mandated-they most definitely are not. Instead, they function much like the role district shape plays in the redistricting context; they signal something may be awry and that closer scrutiny is appropriate. ${ }^{87}$ The degree to which a nominating regime is penetrable and contestable offers a means to gauge the health and vibrancy of the associational and participatory interests of the participants within it. Making assessments of this sort case by case is something the Court has long done, and something it should continue to do.

\section{A CURE WORSE THAN THE DISEASE? THE SPECIAL CASE OF JUDICIAL ELECTIONS}

The Justices have long been uneasy with the practice of electing judges. ${ }^{88}$ This uneasiness was manifest in Lopez Torres not in a criticism of the system plaintiffs challenged, but rather as apprehension about what might follow were the Justices to affirm the lower courts. The district court had already ordered the State to hold direct primaries until the state legislature came up with a constitutional replacement for the invalidated regime. ${ }^{89}$ The Justices worried that this remedy was both worse than the practice it replaced and that it might become permanent.

In concurring opinions, Justice Stevens queried whether "the very practice of electing judges is unwise," 90 while Justice Kennedy wondered whether judicial elections that require candidates "to conduct campaigns and to raise funds" damaged "the perception and the reality of judicial independence." 91 At oral argument, Chief Justice Roberts observed that a purely appointive system was "not a realistic option," after which Justice Ginsburg recalled that a commission studying judicial elections in New York concluded that "the worst thing in the world would be to return us to the primary system this system was intended to replace." 92 Justice Breyer, for his part, said that if counsel for Lopez Torres thought the challenged system was "so terrible . . . [that] the Constitution forbids that, ... you'd have to explain, wouldn't you, why, with all its faults, that is not better in the judgment of New York than a system where people raised $\$ 4$ million from the lawyers in order to run for office?"93

Needless to say, no such explanation was required, nor was any of this speculation about judicial elections even relevant. The hybrid system New York employed to nominate judicial candidates was either unconstitutional or it was not. Given that candidates for judicial office may lawfully be selected by direct primary, what New York might (or might not) do had the Court invalidated the challenged system was, as a matter of law, beside the point.

And yet, for many of the Justices it appeared to be the point that mattered most. It distracted them and may well have colored their view of the merits. Justice Stevens, for example, seemed to think the "glaring deficiencies" the district court found to inhere in New York's system lent support "to the broader proposition that the very practice of electing judges is unwise."94 Judge Gleeson's findings, however, did no such thing. The "glaring deficiencies" he identified - and there were many ${ }^{95}$ —were those that characterize a classic patronage system, and not those typically associated with judicial elections. He identified, for instance, questionable contributions given not to judicial candidates to skew future litigation, but by such candidates to local party bosses to safeguard nominations. ${ }^{96}$ Judge Gleeson's findings lend support not for the claim that electing judges is unwise, but instead for the

\footnotetext{
${ }^{86} \mathrm{Cf}$. Lowenstein, supra note 59, at 1783 (urging judicial restraint not "abdication").

87 See, e.g., Miller v. Johnson, 515 U.S. 900, 913 (1995).

${ }^{88}$ See Republican Party of Minnesota v. White, 536 U.S. 765, 787-88 (2002); see also id. at 788-792 (O'Connor, J., concurring); Sandra Day O'Connor, Justice for Sale, The Wall St. Journal (Nov 15, 2007).

89411 F.Supp.2d at 255-56.

90128 S.Ct. at 801 (Stevens, J., concurring).

91128 S.Ct. at 803.

92 Transcript of Oral Argument, New York St. Bd. of Elections v. Lopez Torres, No. 06-766 (Oct. 3, 2007), at 48, 50.

93 See Oral Argument, supra note 92, at 47.

94128 S.Ct. at 801 (Stevens, J. concurring).

95 See 411 F.Supp. 2d 212.

${ }^{96} \mathrm{Id}$.
} 
proposition that New York's judicial elections are not really elections at all.

Many of the Justices seemed to think that might just be a good thing. New York's judicial nominating regime is a mess, to be sure. But for all the difficulties it presents, it appeared more palatable to a Court squeamish about judicial candidates actively soliciting cash in order to finance a campaign and making the promises candidates seeking election make. ${ }^{97}$ A little backroom decisionmaking might seem a small price to pay to temper such conduct.

Lopez Torres nevertheless made no effort to limit its analysis to judicial elections. ${ }^{98}$ It immunized every smoke-filled room from review, not just the ones that select judicial candidates. The Obama-Clinton contest shows that not all of these rooms stunt political participation and prevent an election from being a "real" election. But some smoke-filled rooms do stymie democratic engagement, and it was this effect that the Court in Lopez Torres sought to encourage.

\section{CONCLUSION}

In his concurring opinion in Lopez Torres, Justice Kennedy expressed considerable discomfort with the practice of electing judges, and closed by wondering whether it might all be otherwise. He contemplated judicial elections of a sort that "offer[ed] the opportunity, indeed the civic obligation, for voters and the community as a whole to become engaged in the legal process." He imagined that "fair and open" judicial elections might even function "as an essential forum for society to discuss and define those attributes of judicial excellence and to find ways to discern those qualities in the candidates." 99

Pie in the sky perhaps, but still not a bad aspiration-not just for judicial elections but for all elections that select public officers. Justice Kennedy suggested implementing his vision would require wide participation from the "organized bar, the legal academy, public advocacy groups, a principled press, and all the other components of functioning democracy." ${ }^{100} \mathrm{He}$ omitted the Court itself from this list of participants. He should have included it and recognized it as an essential "component of functioning democracy." The Court's biggest mistake in Lopez Torres was its refusal to embrace this role, whatever the outcome produced.

Last June's decision in Caperton v. Massey suggests that some Justices may be willing to rethink this stance. Caperton read the Due Process Clause to require the recusal of an elected judge who had received a disproportionately large campaign contribution from a party involved in litigation before him. Caperton relies on a fact-intensive inquiry that insists that courts can meaningfully distinguish permissible campaign contributions from impermissible ones in this context. Vigorous dissents objected with language that echoed the institutional concerns voiced by the unanimous Court in Lopez Torres.

Perhaps Caperton signals a change in direction and the Court will begin to review with rigor not only contribution disputes but challenges to nomination procedures of the sort brought by Judge Lopez Torres. Embracing this role would be a welcome development. Doing so hardly requires the Court to eradicate every nomination process that relies on backroom decisionmaking. Many co-exist with and even facilitate the sort of democratic participation to which Justice Kennedy suggests we should all aspire. One might even argue that the nomination process Obama traversed-with the superdelegates controlling the nomination and the very institutions Justice Kennedy identified actively engaged in their evaluation-came pretty close to realizing the aspiration. But even if it fell short, this smoke-filled room holds far more promise than the one that dominates in New York, where public engagement and vigorous democratic participation remain absent.

Address correspondence to: Ellen D. Katz University of Michigan Law School 645 S. State Street Ann Arbor, MI 48109

E-mail: ekatz@umich.edu

\footnotetext{
${ }^{97}$ See Robert Bauer, The Politics of Judicial Elections, $<$ http://www.moresoftmoneyhardlaw.com/news.html?AID = 1 177>, Jan. 18, 2008.

98 Elemendorf, supra note 59, at 404. A generation ago, the Court seemed to think special rules might govern the election of judges, see Wells v. Edwards, 347 F.Supp. 453, 455 (D.C. La. 1972), summarily aff'd, 409 U.S. 1095 (1973). Subsequent cases insisted that judicial elections are no different from other elections and that the same rules control. See, e.g., Republican Party of Minnesota v. White, 536 U.S. 765 (2002); Chisom v. Roemer, 501 U.S. 380 (1991). Last June's decision, Caperton v. Massey, suggests the Court may be reconsidering this view and returning to its earlier position that judicial elections are distinct.

99128 S.Ct. at 803.

${ }^{100} I d$.
} 